Ján Kováč
Associate Professor
Faculty of Environmental and
Manufacturing Technology
Zvolen,
Slovakia
Jozef Krilek
Associate Professor
Faculty of Environmental and
Manufacturing Technology
Zvolen,
Slovakia
Miroslav Dado
Associate Professor
Faculty of Environmental and
Manufacturing Technology
Zvolen,
Slovakia
Pavel Beňo
Associate Professor
Faculty of Environmental and
Manufacturing Technology
Zvolen,
Slovakia

\section{Investigating the Influence of Design Factors on Noise and Vibrations in the case of Chainsaws for Forestry Work}

\begin{abstract}
In the recent time forest harvesting is mainly related to the use of chainsaws. They are acceptably light, safe, cheap and multifunctional. At the same time, chainsaws can cause personal illnesses considering their vibrations and noise. This article deals with conditions and assessment evaluation of effects on workers caused by vibrations and noise in the case of professional chainsaws in operation. Mechanical vibrations and noise are mainly related to the back-and-forth movement of the piston, and to a lesser extent, to the cutting chain. The experiment revealed, in general, that design parameters have a minimal influence on chainsaw vibration and noise emissions. Specifically, the statistical analysis for frequency weighted vibration showed no difference between types of guide bars, types of saw chains and wood plant in terms of noise and vibration on handles.
\end{abstract}

Keywords: forest harvesting, chainsaw, noise of chainsaws, ergonomic, vibration, cutting wood, HAV human.

\section{INTRODUCTION}

Forest harvesting operation is undeniably a hard work with high risk of accident and health problem for its workers. Several studies proved that this kind of working activity burdens the workers with excessive physic a workload, between $49-79 \%$ of the $\mathrm{V}_{\mathrm{dot}} \mathrm{O}_{2}{ }^{\max }$ [1] and beyond the permissible standard [2].

An efficient wood harvesting action aims at fully recovering wood as a measure to maximize the profit [3], also in terms of new methods for machining plans optimisation [4] or technical solutions for improving the equipment efficiency [5-6]. But safety prescriptions should be obeyed each time when harvesting operations are performed [7]. At the same time on-site activity takes place in very different conditions compared to traditional operations, as in the case of sawmills or woodworking factories, where numerous measures can be adopted to reduce all risks (as vibration, noise, VOC, 'projectiles') for workers [8-9] and environment [10] .

Despite technological advancements that resulted in a wide range of machinery for wood harvesting, chainsaws are frequently used in forest operations [11]. Inappropriate chainsaw operations i.e. bad maintenance and lack of safety equipment may worsen the effects of gas emission, noise, and vibration [2]. The work of a chainsaw operator is characterized not only by a large physical load and high risk of accidents, but it also endangers his health in other ways, of which vibrations and noise are the most important [12].

Petrol-fuelled chainsaws, commonly used in forestry, produce noise, which may lead, among others things, to the

Received: October 2017, Accepted: February 2018

Correspondence to: doc. Ing. Pavel Beňo, PhD.

Technical University in Zvolen,

T.G. Masaryka 24, 96053 Zvolen, Slovakia

E-mail: pavel.beno@tuzvo.sk

doi:10.5937/fmet1804513K

(C) Faculty of Mechanical Engineering, Belgrade. All rights reserved development of noise-induced hearing loss of the operator.

According to Machinery Directive 2006/42/EC [13], a chainsaw should be designed and manufactured in the way to reduce, as possible, the risks resulting from emission noise, taking into account all technical progress and all means available to reduce noise, especially at source.

In an internal combustion chainsaw, in particular, the main noise sources are aerodynamic processes proceeded in the engine, mechanical processes resulted from operation of the piston-crank system, friction in bearings, ejection of exhaust gasses and movement of saw chain over the guide bar.

The level of generated noise is also influenced by power of the chainsaw used in timber harvesting [14]. In order to evaluate the possibilities for noise reduction, in [15] a noise source identification and ranking using the acoustic intensity method was performed. Results of measurements showed that noise reduction of the chainsaw is extremely difficult due to the many partial noise sources with comparable sound power.

Laboratory tests were conducted on the efficiency of guide bar vibration damping, and thus ambient noise, for selected mineral and vegetable oils applied in the cutting system of the chainsaw at specially prepared testing stand during movement of chainsaw along a guide bar without cutting wood [16]. Results showed that under identical conditions similar elements of the cutting system, collected from the same unit, may emit different noise levels as a result of application of different oils. Further, the level of generated noise is also influenced by cutting part of chainsaw during wood cutting. In [17] it was found that higher noise level is generated during cross cutting with upper side of the guide bar and that kerf height affects significantly the level of emitted noise.

Mechanical vibrations in a chainsaw are mainly caused by the back-and-forth movement of the piston, 
and to a lesser extent by the cutting chain. The latter causes vibrations due to varying forces affecting the cutters which penetrate the wood [18] (Wójcik, 2002). These forces are causes by the resistance of the wood to cutting, which depends on a number of reasons, like the shape and condition of the cutters [19]. The vibration levels resulting from the cutting chain working in the wood depend on the place (front or rear handle) and the direction ( $\mathrm{x}, \mathrm{y}, \mathrm{z}$ axis) of the measurement. In [20] the importance of two other factors that affect the vibration levels, namely the pushing force applied to the saw and gauge depths of the cutters, which have a direct effect on the resistance of wood to cutting was stressed. Results of experimental investigations performed by [9] showed statistically significant differences between the vibration levels and top plate filing angle values. Another factor which affects the vibrations emitted by chainsaws is the way the operators work with these machines. This problem was studied by [21], who tested vibration levels when cutting wood logs of different diameters with the upper and lower sides of the bar. These results proved that both the working techniques as well as the wood log diameters significantly affected the vibrations.

\subsection{Hand - arm vibrations}

For the purpose of the study of the hand-arm vibration levels there has been introduced a local co-ordinate system for the uniform data exchange as illustrated in the fig. 1 [22].

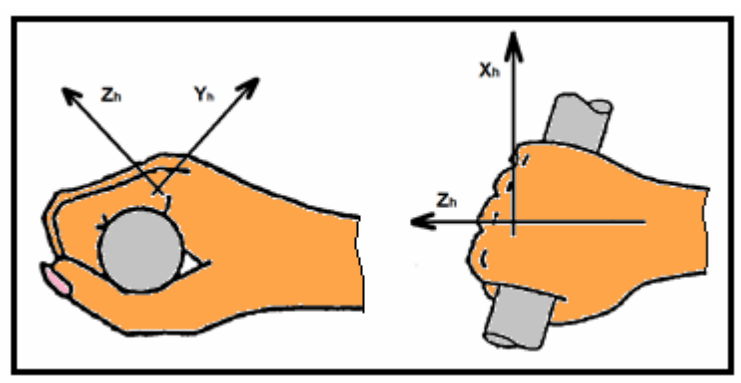

Figure 1. Evaluation system for the hand-arm vibration levels [22]

The main source of vibrations transmitted into the hands-arms in the vehicle is the steering wheel. The driver subjectively perceives this vibration in a very negative way, however it is not considered as very dangerous for the driver from the physiological point of view as well as with regard to hygienic standards [2324]. The health of the operator is in such case much more endangered by the reduced active safety usually interconnected with the steering wheel vibrations. On the other hand the operators of the heavy off-road machines can suffer from vasoneurosis caused by this profession [19].

Typical activity that affects the hand-arm vibration is the work with pneumatic manual tools or chainsaws. In such cases the hand-arm exposition is much higher than operating a mobile forestry machine and the hygienic standards are often exceeded [25-27]. Observing the contact level between the hand-arm and vibration tool or control element shall become a standard proceeding [28].
This approach involves measuring and recording of the vibrations transmitted to hand-arm in all three coordinates, spectral analysis of these records and comparison with respective limit curve given by the specific exposition time. Since the mentioned procedures is very rare, people working with pneumatic tools often suffer from so called Hand - Arm Syndrome, the complex reaction of the organism to uncontrollable exposition [29]. In such cases it can lead to irreversible damage of muscular, vessel, nerve and skeleton handarm system. It is interesting to mention the temperature influence often observed in many researches. The vibration impact on human body increases with decreasing temperature of the environment [30].

\section{MATERIALS AND METHODS}

The experiments were carried out with two types of cutter teeth: chisel, micro-chisel (Figure 2, Table 1). The noise measurements were performed in open air site, away from elements that could cause sound absorbing. Test site was covered with the mixture of concrete and asphalt. Measurements of the equivalent Aweighted emission sound pressure levels were made using two integrating sound level meters (f. B\&K, type 2239).

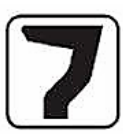

chisel

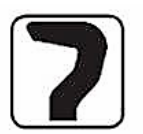

semi chisel
Figure 2. Types of cutting teeth

Table 1. Specifications of saw chains under investigation

\begin{tabular}{|c|c|c|c|}
\hline $\begin{array}{c}\text { Manufacturer } \\
\text { and type of saw } \\
\text { chain }\end{array}$ & $\begin{array}{c}\text { Chain pitch } \\
(\mathrm{mm})\end{array}$ & $\begin{array}{c}\text { Chain gauge } \\
(\mathrm{mm})\end{array}$ & $\begin{array}{c}\text { Cutter } \\
\text { style }\end{array}$ \\
\hline Husqvarna H42 & 9,525 & 1,5 & ch \\
\hline Stihl RD & 9,525 & 1,6 & ch \\
\hline Husqvarna H54 & 9,525 & 1,5 & sch \\
\hline Stihl RMC & 9,525 & 1,6 & sch \\
\hline
\end{tabular}

During measurement, the first microphone was placed at a height of $150 \mathrm{~cm}$ the second microphone was placed at the side of the chainsaw in the distance $7.5 \mathrm{~m}$ and height $1.5 \mathrm{~m}$ (Fig. 3). The measurement methodology was designed on the basis of different construction of emission pipe of a chainsaw. The noise levels were measured during the operation of crosscutting, on fresh felled spruce log with $35 \mathrm{~cm}$ diameter. The log was placed $60 \mathrm{~cm}$ above the ground and during the cross-cutting $5 \mathrm{~cm}$ thick wood discs were cut off. Measurements were carried out on a new machine (f. Husqvarna, type XP 550, Husqvarna, type XP 576, Stihl MS 260, Stihl MS 461) fitted with standard equipment in accordance with instruction book. To assure the similar cutting conditions, the wood was crosscut by the same operator. Saw chains (f. Husqvarna, f. Stihl) were new a tensioned according to instruction book. The ambient air temperature was $18^{\circ} \mathrm{C}$, and the wind speed was less than $1 \mathrm{~m} / \mathrm{s}$. 
The data set was comprised of twenty samples for each of the two types of cutting teeth. Difference between the sound pressure levels measured at microphone position, with the chainsaw under test in operation and turned off was more than $15 \mathrm{~dB}$, so correction for background noise could be neglected. Identification of potential differences between the examined types of cutting teeth was conducted with help of analysis of variance (ANOVA), which is included in software package (f. StatSoft ${ }^{\circledR}$, Statistica v. 10). Post-hoc analysis for investigating potential differences between cutting chains was done using Bonferroni's test. Significance level for all tests was set at $5 \%$.

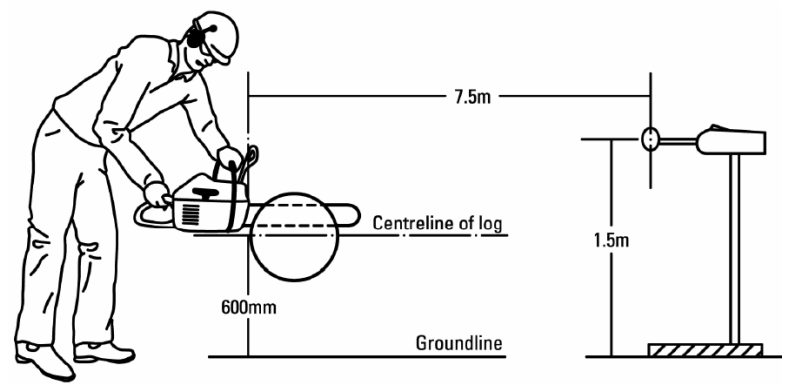

Figure 3. Experiment set-up (EPA, 2008 [31])

A large number of standards, both at international and national levels, define methods and rules regarding similar aspects [32-36]. In particular, the present experiments were based on requirements according to STN EN ISO 22867:2012, STN EN ISO 5349-1:2003 and STN EN ISO 5349-2 (see Figure 4). Measurements were carried out on a new machine (f. STIHL, type MS 261, f. Husqvarna, type 550XP), featuring standard equipment as provided by the manufacturer.

For the research there were used two types of the most spread and used chainsaws from the category medium heavy duty. For every type of a chainsaw there were used guide bars and saw chains recom-mended by producer. For the cutting process there were used two wood species i.e. beech (Fagus sylvatica) and spruce (Picea abies). This wood was fresh with moisture over viber saturation point. The measurements were held outside in the area of VDL TU in Zvolen.

\section{Husqvarna 550 XP}

- The type of guide bar with a pitch of saw chain planing teeth 0,325 Oregon and Husqvarna.

- Thy type of guide bar for saw chains with the pitch of the saw chain planing teeth $3 / 8$ Oregon and Husqvarna.

- The saw chain Husqvarna: H21_0.325, H25_0.325, H42_3/8, H54_3/8.

- The saw chain Oregon: M21LPX 0.325, 21LPX 0.325, 21BPX_0.325, 73LPX_3/8, M73LPX_3/8, 73DP_3/8

\section{Stihl MS 261}

- The type of guide bar with the pitch of planing teeth 0,325 Stihl rollomatic and duromatic (without guide wheel).

- The type of the guide bar for saw chains with the pitch of planing teeth $3 / 8$ Stihl rollomatic and duromatic (without guide wheel).
- The saw chains Stihl: RS_0.325, RMC_0.325, RD3_0.325, RSC_3/8, RMC_3/8, RD_3/8.

Table 2. Basic technical parameters of chainsaws

\begin{tabular}{|c|c|c|}
\hline Type of Chainsaw & Stihl MS 261 & $\begin{array}{c}\text { Husqvarna } \\
550 \text { XP }\end{array}$ \\
\hline Cylinder, $\mathrm{cm}^{3}$ & $50,2 \mathrm{~cm} 3$ & $50,1 \mathrm{~cm}^{3}$ \\
\hline Performance, $\mathrm{kW}$ & $2,8 / 3,8 \mathrm{~kW} / \mathrm{k}$ & $2,8 \mathrm{~kW}$ \\
\hline Weight, $\mathrm{kg}$ & $5,2 \mathrm{~kg}$ & $4,9 \mathrm{~kg}$ \\
\hline
\end{tabular}

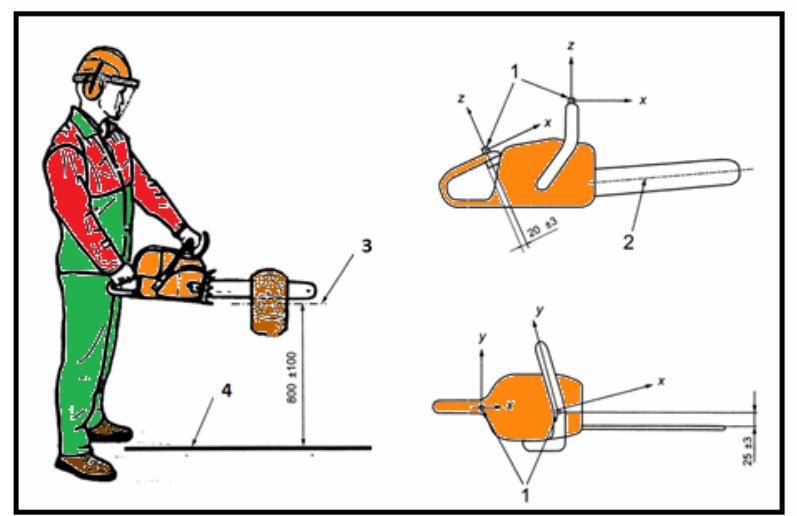

Figure 4. Chainsaw position, measuring directions and positioning of accelerometers. All dimensions in millimeters. 1 - accelerometer, 2 - guide bar centreline 3 centreline of log 4 - ground plane [STN EN ISO 22867, 2012]

Measurements were carried out in the following operating modes: idling, full load and racing. The measure chain consists of tri-axial accelerometer ( $\mathrm{f}$. Norsonic, type 1287) and vibration analyzer (f. Norsonic, type 133). The accelerometer on the rear handle was located $20 \mathrm{~mm} \pm 3 \mathrm{~mm}$ in front of the rear of throttle trigger. The accelerometer on the front handle was located $25 \mathrm{~mm} \pm 3 \mathrm{~mm}$ to the left of the guide bar plane. from:

The equivalent vibration total value was determined

$$
a h v, e q=\left[\frac{1}{3}\left(\bar{a} h v, I d^{2}+\bar{a} h v, F l^{2}+\bar{a} h v, R a^{2}\right)\right]^{1 / 2}
$$

$\bar{a} h v, I d$ - arithmetic mean value of equivalent weighted vibration for idling,

$\bar{a} h v, F l$ - arithmetic mean value of equivalent weighted vibration for full load,

$\bar{a} h v, R a$ - arithmetic mean value of equivalent weighted vibration for racing.

\section{RESULTS AND DISCUSSION}

The aim of presented article was to measure timeaveraged sound pressure levels emitted by chainsaw and to find interaction between noise emission quantity and type of cutter tooth [37]. It is possible to evaluate noise loading by measurement of noise level, evaluation of spectrum and defining level of acoustic performance. In this case the limit value of noise loading is $85 \mathrm{~dB}$ given by standards. After overtaking the value, it is necessary to take measures to eliminate negative values of noise to protect the health of workers. Mostly all chainsaws 
overtake the noise level limited value and the noise value is in the range of $96-105 \mathrm{~dB}$. Producers defines this level in the range of $99-115 \mathrm{~dB}$ this time.

The results of ANOVA have confirmed important influences of cutting tooth profile on magnitude of noise emitted by chainsaw during cross cutting of wood (Fig. $3,4,5,6)$. The figures 3 and 4 show results of statistical evaluation for measured chainsaws namely Husqvarna XP 550 and Stihl MS 261.

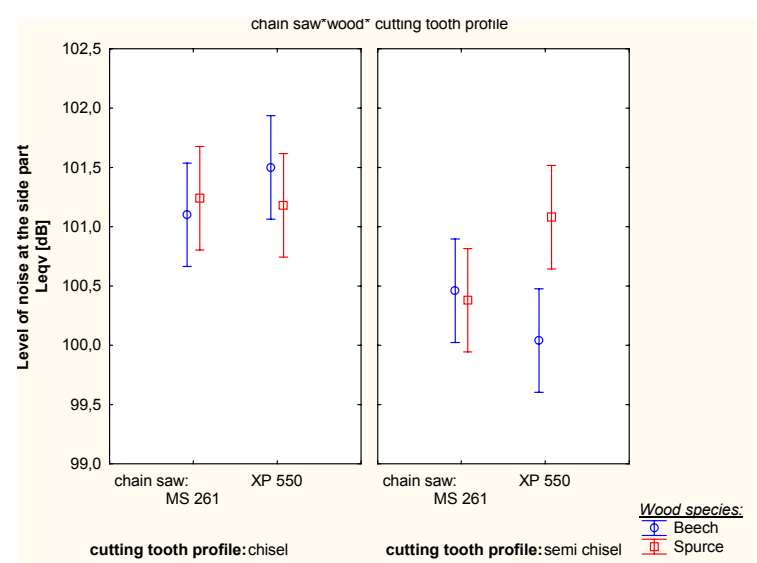

Figure 5. Results of ANOVA analysis - level of noise at the side part of a chainsaw

For planning teeth chisel there was not confirmed statistical difference. From figure 3 we can see that the influence of planning teeth was confirmed. According to the statistical results we can say that the chainsaw MS 261 has lower intensity of noise than XP 550. The same we can say regarding to wood species where the intensity of noise was lower at spruce wood than at beech wood which might be caused by structure of wood.

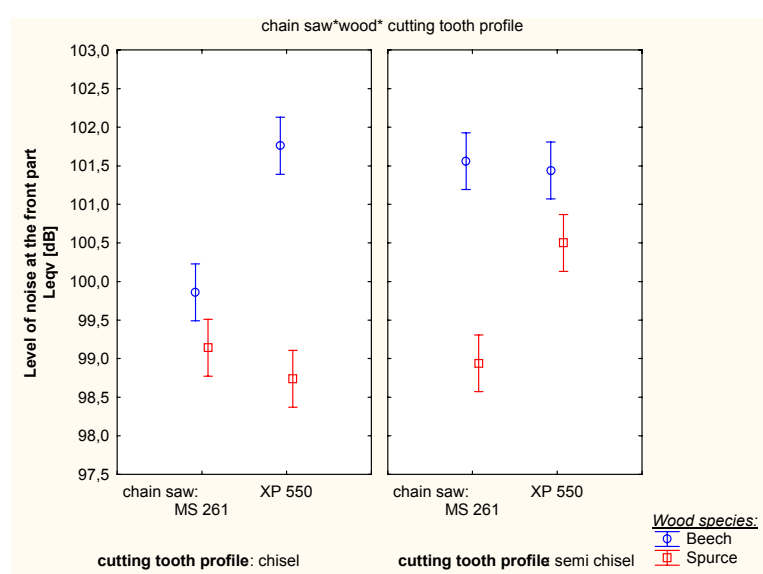

Figure 6. Results of ANOVA analysis - level of noise at the front part of a chainsaw

From the results in figure 4 we can say that the influence of the chainsaw type is significant according to the noise intensity. With the high probability we can say that intensity of noise is lower at spruce wood that at beech wood. Regarding the profile of semichisel planning tooth there is lower intensity of noise. In the results there is shown the difference between a profile of a planning tooth and wood species regarding to the intensity of noise. This fact is caused by the position of emission pipe i.e. at Stihl MS 261 it is placed at the side part of the chainsaw and at Husquarna XP 550 it is placed at the front part of the chainsaw.

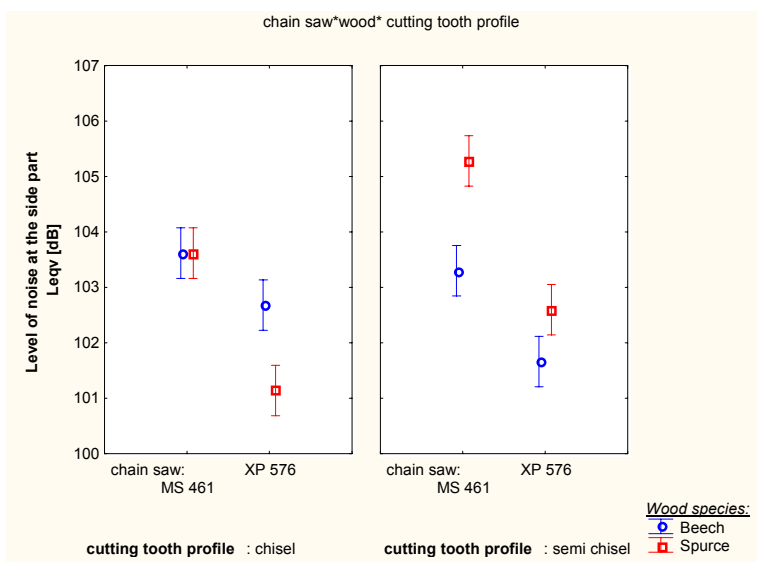

Figure 7. Results of ANOVA analysis - level of noise at the side part of a chainsaw

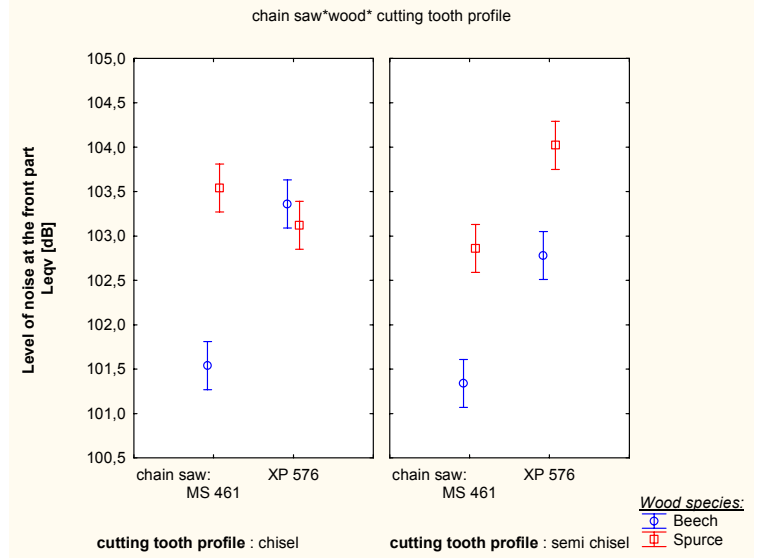

Figure 8. Results of ANOVA analysis - level of noise at the front part of a chainsaw

In fig. 5 and 6 there are shown results of statistical evaluation from measurements performed on chainsaws Husqvarna XP 576 a Stihl MS 461. We can say that there are the same results as at chainsaws mentioned above. The given results show that the engine part of the chainsaw has high influence on the intensity of noise.

The goal of measurements was to find out the value of vibrations on the front and back handle of the chosen types of chainsaws in different types of saw chains and guide bars cutting wood. For evaluation of measured data there were used Wilcoxonov test and KruskalWallisov test and for graphical presentation there were used point graphs 3 and 4. There were evaluated vibration values a - weighted mean of vibrations, which is given by formula 1 and calculated from:

- Vibrations - idle

- Vibrations - maximum revolutions without loading

- Vibrations - during wood cutting $a_{F}$.

Then there were evaluated vibrations values $\boldsymbol{a}_{\boldsymbol{F}}-$ mean vibration values during wood cutting by chainsaw.

During measurement it was found that the highest levels of vibrations were recorded during idle running of chainsaws and the lowest levels were recorded during maximum revolutions. On the chainsaw Stihl MS 261 there were used two types of guide bars namely duromatic and rollomatic. From the viewpoint of vibration evaluation, it was not shown statistical difference for the used types of guide bars. The evaluation says that using the chainsaw Stihl MS 261 the vibrations are the lowest in both types of guide bars 


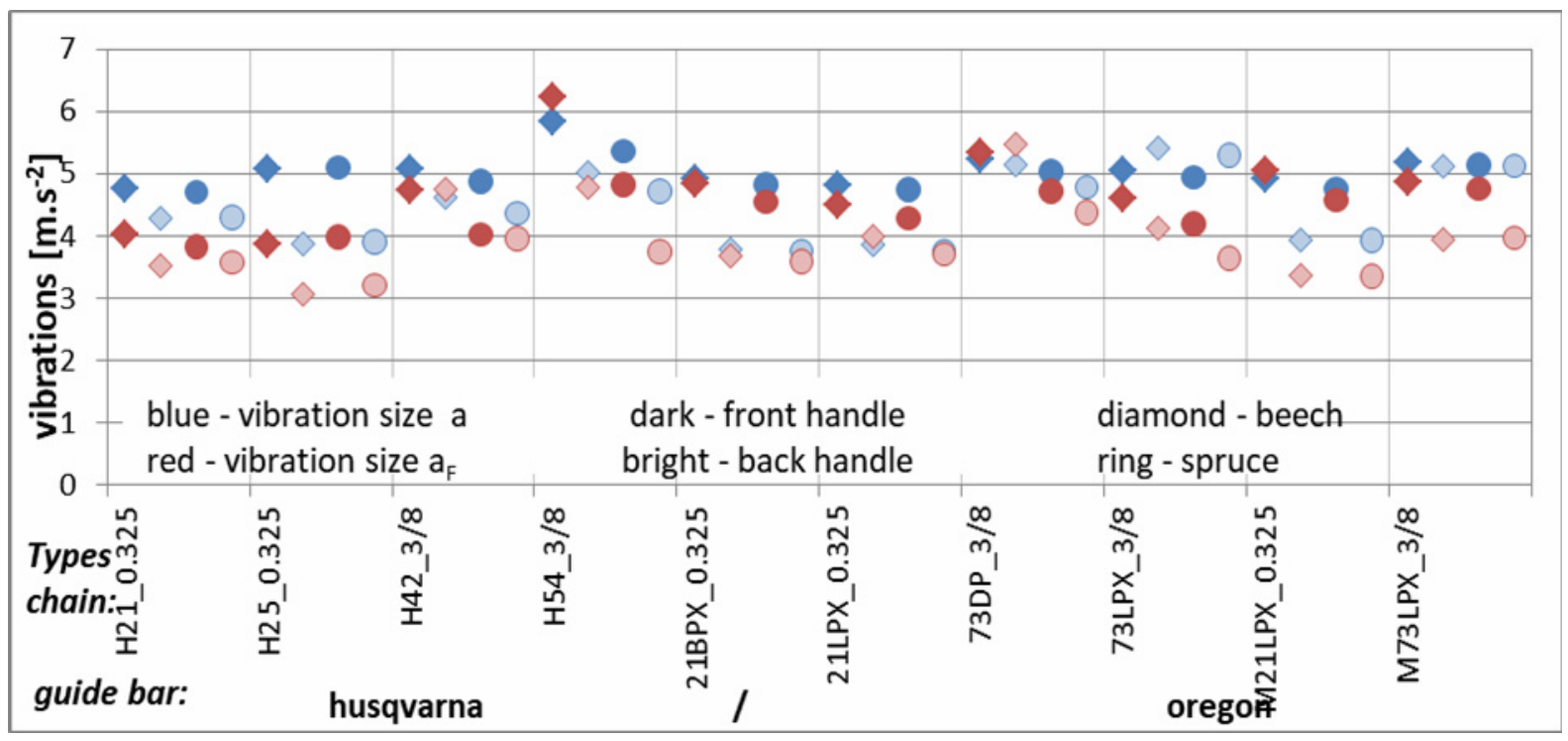

Figure 9. Influence of all factors on size of vibrations $a\left(\mathrm{~m} . \mathrm{s}^{-2}\right)$ and $a_{F}\left(\mathrm{~m} . \mathrm{s}^{-2}\right)$ on the chainsaw Husqvarna 550 XP

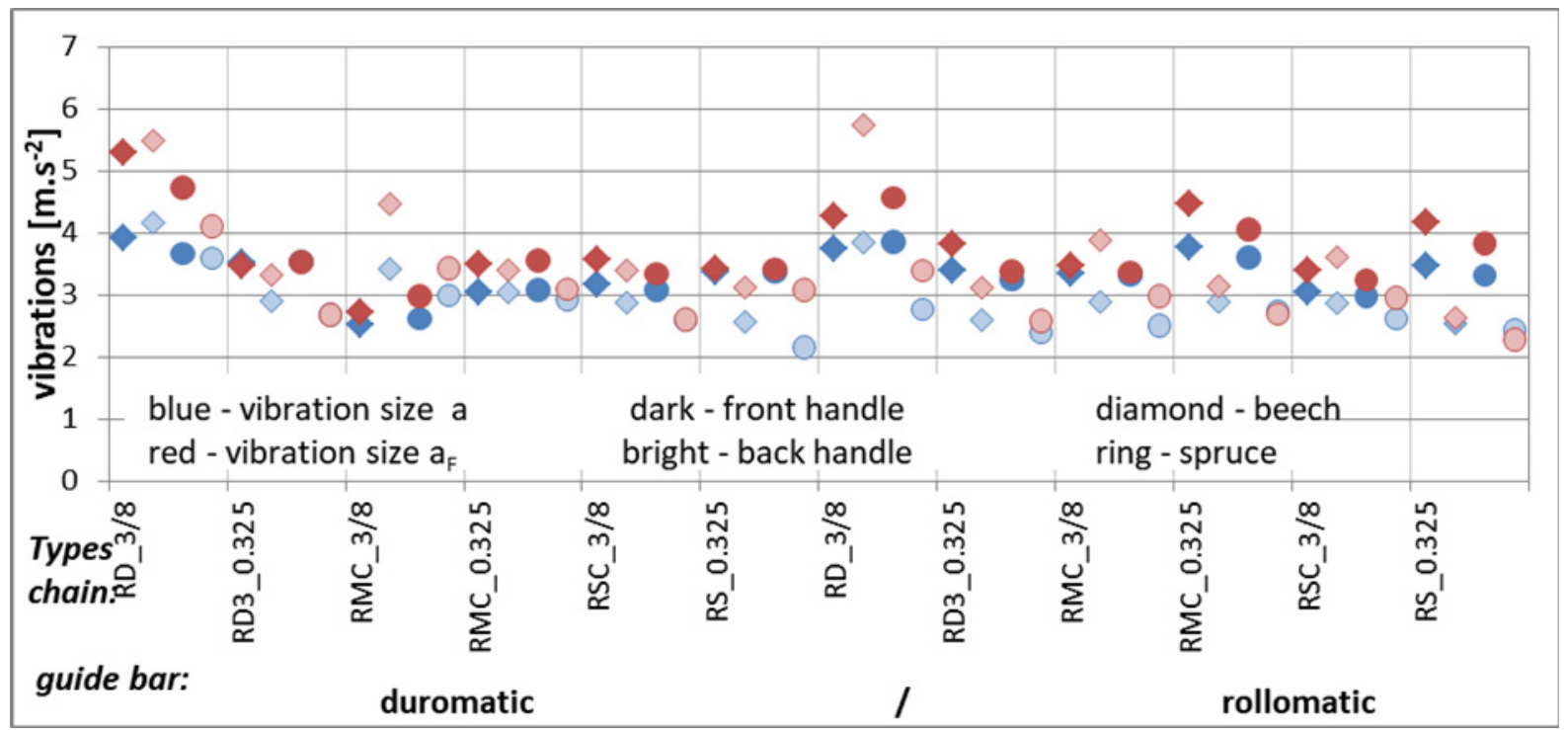

Figure 10. Influence of all factors on size of vibrations $a\left(\mathrm{~m} . \mathrm{s}^{-2}\right)$ and $a_{F}\left(\mathrm{~m} . \mathrm{s}^{-2}\right)$ on the chainsaw Stihl MS 261

with a guide wheel and without a guide wheel as well. In comparison with Husqvarnou $550 \mathrm{XP}$, which is the most similar to Stihl MS 261 according to the tech-nical parameters, it has higher vibrations. For the given chainsaw there were recorded the best vibration indicators for the saw chains H21 0,325 and H25 0,325. Because of this we can say that the pitch of planing teeth has influence on the size of vibrations and better indicators were recorded on the chainsaws with a pitch.

\section{CONCLUSION}

The basic source of noise of such designed chainsaws is a motor part. The air cooled one cylinder two stroke combustion engine (low weight) is more noisy than water cooled one (more cylinder four stroke one). The further sources of noise are either driven by an engine or they transmit noise of the engine. They include: a fuel tank, a fan, an exhaust pipe noise absorber, a guide bar with a saw chain, an air admission, chainsaw covers.

Planning tooth size, shape and leading edge determine the efficiency and durability of a saw chain.
The experiment revealed that cutting chain design also influences the magnitude of chainsaw noise emissions. All measured values are lower than the value declared by manufacturer due to different noise measurements methods. In further research, it would be interesting to repeat the experiment in other microphone positions, tree species as well as chainsaw types.

Interaction between a saw chain and the type of a chainsaw regarding the size of vibrations on the medium heavy duty chainsaws was considerably noticeable. Interaction of a saw chain has not shown the vibration difference. Evaluation of chainsaws in the interaction of the type of a saw chain has not shown the difference and that is why we can say that a type of the saw chain does not have influence on the size of vibrations.

The influence of wood during the cutting process has shown significant values and we can say that at spruce wood cutting there are vibrations lower than at beech wood cutting. This fact is caused by physical and mechanical wood properties. Soft wood absorbs vibrations better than hard wood (better vibration transmissions). 


\section{ACKNOWLEDGMENT}

This investigation was realized inside VEGA project (ref. 1/0826/15) aiming to research cutting mechanisms in the processing wood materials, and KEGA project aiming to propose forms and methods of innovations within the educational process in the field of agricultural and forest technology (ref. 019TU Z-4/2015)

\section{REFERENCES}

[1] Yovi, E., Takimoto, Y., Ichihara, K. and Matsubara, C.: A study of workload and work efficiency in timber harvesting by using chainsaw in pine plantation forest in Java Island (2): thinning operation, Applied Forest Science, Vol. 15, No. 1, pp. 23-31, 2006.

[2] Yovi, E., Takimoto, Y., Ichihara, K. and Matsubara, C.: A study of workload and work efficiency in timber harvesting by using chainsaw in pine plantation forest in Java Island: clear cutting operation, Applied Forest Science, Vol. 14, No. 1, pp. 17-26, 2005.

[3] Milovanovic, M.B., Antic, D.S. et al.: Wood resource management using an endocrine NARX neural network. European Journal of Wood and Wood Products. Vol. 76, No. 2, pp. 687-697, 2018, DOI: $10.1007 / \mathrm{s} 00107-017-1223-6$.

[4] Djapic, M., Lukic, L. et al.: Multi-agent team for engineering: a machining plan in intelligent manufacturing systems. International Journal of Manufacturing, Materials, and Mechanical Engineering. Vol 19, No. 6: pp. 505-521, 2017.

[5] Nedić, N., Prsic, D., et al.: Simulation of Hydraulic Check Valve for Forestry Equipment, International Journal of Heavy Vehicle Systems, Vol. 24, No. 3, pp. 260-276, 2017. doi: 10.1504/IJHVS..10001493.

[6] Zigulic, R., Fragassa, C. and Skoblar, A.: Influence of the longitudinal displacement on nonlinear principal parametric resonance of the woodworking bandsaw, Tehnicki Vjesnik, Vol. 24, No. 1, pp. 253-263, 2017.

[7] Borz, et al.: Timber felling procedures, BioResources, Vol. 9, No. 4, pp. 6938-6949, 2014.

[8] Pavlovic, A. and Fragassa, C: Numerical modelling the ballistic impacts on flexible curtains used as safety protection in woodworking, Proceedings of the Institution of Mechanical Engineers, Part C: Journal of Mechanical Engineering Science, Vol 231, No. 1, pp. 44-58, 2017.

[9] Fragassa, C.: Material selection in machine design: the change of cast iron for improving the highquality in woodworking, Proceedings of the Institution of Mechanical Engineers, Part C: Journal of Mechanical Engineering Science, Vol 231, No. 1, pp. 18-30, 2017.

[10] Bulian, F. and Fragassa, C.: VOC emissions from wood products and furniture: a survey about legislation, standards and data referred to different materials, FME Transactions, Vol. 44, No. 4, pp. 358-364, 2016.
[11]Rottensteiner, C., Tsioras, P. and Stampfer, K.: Wood Density Impact on Hand-Arm Vibration, Croatian Journal of Forest Engineering, Vol. 33, No. 2, pp. 303-312, 2012.

[12] Stempski, W., Jablonski, K. and Wegner, J.: Relations between top-plate filling angle values of cutting chains and chainsaw vibration levels, Acta Scientarium Polonorum, Vol. 9, No. 2, pp. 31-39, 2010.

[13] Directive 2002/44/Ec Of The European Parliament And Of The Council, on the minimum health and safety requirements regarding the exposure of workers to the risks arising from physical agents (vibration) (sixteenth individual Directive within the meaning of Article 16(1) of Directive 89/391/EEC).

[14] Kováč, J.: Analysis of the noise of chainsaw influence on the human body, Acta Facultatis Technicae, Vol. 17, No. 3, pp. 139-146, 2012.

[15] Astrup, T.: Measurement of sound power using the acoustic intensity method - a consultant's viewpoint, Applied Acoustics, Vol. 50, No. 2, pp. 111-123, 1997.

[16] Wojtkoviak, R., Kromulski, J. and Dubowski, A.: Measurement of noise resulting from cutting chain movements on chain-saw bar, lubricated with different oils, Acta Sci. Pol., Silv. Colendar. Rat. Ind. Lignar. Vol. 6, No. 1, pp. 85-93, 2007.

[17] Skarzynski, J. and Lipinski, R.: Effect of kerf height on noise emission level in the internal combustion chainsaw Stihl MS 211 and the electric chainsaw Stihl E $180 \mathrm{C}$ during cross cutting of wood, Annals of Warsaw University of Life Sciences - SGGW, Agriculture, No. 62, pp. 55-62, 2013.

[18] Wojcik, K.: Analysis of processing operation time and its percent share in timber harvesting with the chainsaws, Annals of Warsaw Agricultural University, Vol. 50, pp. 71-77, 2007.

[19] Kováč, J., Krilek, J., Dvořák, J. and Beňo, P.: Noise and Vibration of Chainsaws (in Slovak), Technická univerzita vo Zvolene, 2014.

[20] Sowa J. M.: Analysis of threats caused by vibrations to chainsaw operators (in Polish). Zast. Ergon. 1, 2, 3, 189-196, 1998.

[21] Skarżyński J.: Effects of wood diameter on vibrations on chainsaw handles during crosscutting (in Polish), Techn. Roln. Ogrod. Leśn. 5, 2007.

[22] Dado, M., Hnilica, R. and Krilek, J.: The Effect of a Guide Rail Type on the Chainsaw Vibration Magnitude (in Slovak), Fyzikálne faktory prostredia: časopis o problematike fyzikálnych faktorov prostredia, Vol. 3, No. 2, pp. 11-14, 2013.

[23] Václav, Š.: Theoretical Aspect of Assembly, Hochschule Anhalt, 2013.

[24] Gubeljak, N., Chapetti, M., Predan J. and Landes. J.: CTOD-R curve construction from surface displacement measurements, Eng. fract. mech., Vol. 78, No. 11, pp. 2286-2297, 2012. 
[25] Holmlund, P. and Lundström R.: Mechanical Impedance of the Human Body in the Horizontal Direction, Journal of Sound and Vibration, Vol. 215, pp. 801-812, 1998.

[26] Holmlund, P., Lundström, R. and Lindberg, L.: Mechanical Impedance of the Human Body in Vertical Direction, Applied Ergonomics, Vol. 31, pp. 415-422, 2000.

[27] Holmlund, P. and Lundström, R.: Mechanical Impedance of the Sitting Human Body in SingleAxis Compared to Multi-Axis Whole-Body Vibration Exposure, Clinical Biomechanics, Vol. 16, pp. 101-110, 2001.

[28] Matsumoto, Y. and Griffin, M.J.: Comparison of Biodynamic Response in Standing and Seated Human Bodies, Journal of Sound and Vibration, Vol. 238, No. 4, pp. 691-704, 2000.

[29] Václav, Š.: The Methodology for Calculating the Degree of Complexity of the Parts Orientation in Vibration Trays, MM Science Journal, Vol. 2013, No. 3, pp. 406- 409, 2013.

[30] Dado, M. and Hnilica, R.: Effect of cutting chain design on noise emitted by chainsaw: preliminary results, Nové trendy akustického spektra, 2014.

[31] EPA: Noise procedures measurement manual, 2008.

[32] STN EN ISO 22867:2012. Forestry and gardening machinery. Vibration test code for portable handheld machines with internal combustion engine. Vibration at the handles.

[33] STN EN ISO 5349-1, (2003). Mechanical vibration. Measurement and evaluation of human exposure to hand-transmitted vibration. Part 1: General requirements.

[34] STN EN ISO 5349-2, (2003). Mechanical vibration - Measurement and evaluation of human exposure to hand-transmitted vibration. Part 2: Practical guidance for measurement at the workplace.

[35] STN EN ISO 22868. Forestry machinery - Noise test code for portable hand-held machines with internal combustion engine - Engineering method (Grade 2 accuracy) (in Slovak), 2007.

[36] STN ISO 9207. Manually portable chain-saws with internal combustion engine. Determination of sound power levels. Engineering method (grade 2) (in Slovak), 2000.

[37] Dado, M., Hnilica, R. and Krilek, J.: A Research of a saw chain type effect on the chainsaw vibration magnitude (in Slovak), Fyzikálne faktory prostredia: mimoriadne číslo časopisu o problematike fyzikálnych faktorov prostredia, Vol. 4, No. 2, pp. 22-25, 2014.

\section{ИСТРАЖИВАЊЕ УТИЦАЈА ФАКТОРА ДИЗАЈНА НА БУКУ И ВИБРАЦИЈЕ У СЛУЧАЈУ МОТОРНИХ ТЕСТЕРА ЗА ШУМАРСТВО}

\section{Ј. Ковач, Ј. Крилек, М. Дадо, П. Бено}

Недавно је сакупљање шума углавном повезано са употребом ланчаних тестера. Прихватљиво су лаке, сигурне, јефтине и мултифункционалне. Истовремено, ланчане тестере могу изазвати личне болести узимајус́и у обзир њихове вибрације и буку.

Овај чланак се бави условима и проценом ефеката на раднике узроковане вибрацијама и буком у случају професионалних ланчаних тестера у раду. Механичке вибрације и бука углавном се односе на кретање клипа и, у мањој мери, ланаца за сечење. Експеримент је уопштено показао да параметри пројектовања имају минималан утицај на вибрације и емисије буке. Конкретно, статистичка анализа за вибрације фреквентним пондерисањем није показала разлику између типова водилице, врста ланаца за тестере и дрвне биљке у смислу буке и вибрација на ручкама. 